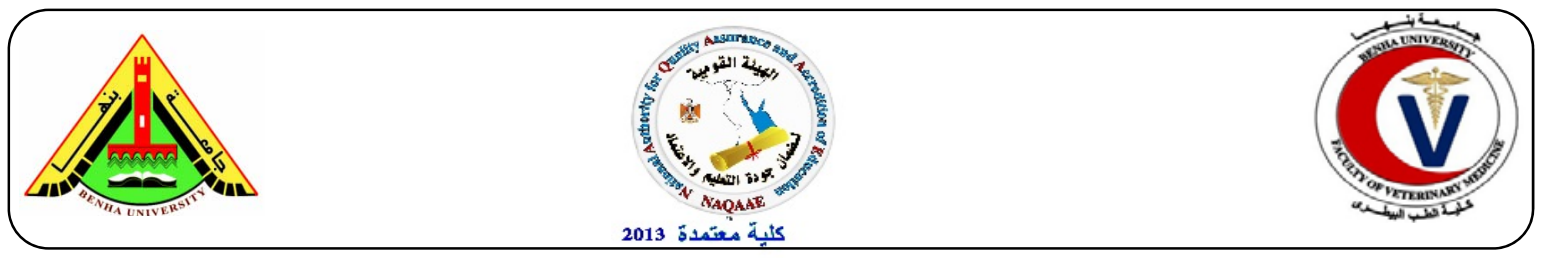

\title{
Protozoal incidence in balady chicken flocks after viral vaccinations
}

Ramadan, M. Y. ${ }^{1}$, Khater, H. F. ${ }^{1}$, Seddiek, S.A. ${ }^{2}$ and Abd El-Aty, M.A. ${ }^{3}$

${ }^{1}$ Department of parasitology, faculty of Veterinary Medicine. Benha University

${ }^{2}$ Animal health research institute-Benha. ${ }^{3}$ Animal health research institute-Shebin El-Koam.

\section{A B S T R A C T}

The present study aimed to detect the incidence of protozoan parasites and their disease severity in balady chickens in relation to the routine viral vaccinations against Newcastle, Infectious bronchitis and Infectious bursal diseases. For this purpose, eight hundred balady chicks divided to 8 equal groups, 4 groups not artificially infected by Eimeria while the other 4groups were artificially infected. The collected samples were examined daily and the detected protozoa were Eimeria spp. (31\%) and Cryptosporidium spp. (10\%) during the vaccination period. The vaccinal dynamic revealed that the highest incidence of Eimeria (64\%) was recorded in G2, while minimum oocyst count / gm feces ( $\left.0.25 \times 10^{3}\right)$ in $\mathrm{G} 6$ at 14 days old, then a rapid, increase, specially 1- 2 days old after each vaccinal application to reach maximum $\left(35 \times 10^{3}\right)$ at the 30 days old. The lowest incidence of Eimeria spp., was in G $1 \& \mathrm{G} 3(0 \%)$ and the minimum oocyst count / gm feces $\left(0.1 \times 10^{3}\right)$ and gradually increased to reach maximum $\left(0.45 \times 10^{3}\right)$ at 18 days old, then decreased again to $\left(0.1 \times 10^{3}\right)$ at the end of experiment in $\mathrm{G} 7$. It was concluded that stress caused by viral vaccinations affecting both incidence and severity of protozoal diseases, especially Eimeria on non-treated chicken groups.

Key words: Protozoa; chicken; viral vaccines; Eimeria, Cryptosporidium.

(http://www.bvmj.bu.edu.eg)

(BVMJ-29(1): 105-111, 2015)

\section{Introduction}

$\mathrm{P}$ oultry sector is not only a source of animal protein, but also play a vital role in the employment generation, Unfortunately is adversely affected by the protozoan parasites mainly genus Eimeria which cause coccidiosis, and genus Cryptosporidium that cause cryptosporidiosis (Meeusen et al., 2007). Coccidiosis is an important disease, especially in poultry industry, and it is one of the most widely reported and economically important diseases affecting commercial poultry production, with an estimated cost over $\$ 800$ million USD annually in the United States and in excess of $\$ 3$ billion USD worldwide (Blake and Tomley, 2014). Coccidiosis and cryptosporidiosis develop in various regions in the gut affecting poultry flocks, and they cause mild to severe lesions, weight loss, diarrhea and increased mortality (Chapman, 2014). Balady chicken strains grow more slowly and need 17 weeks to reach slaughter, therefore it could complete at most 3 cycles per year, which refers to the high cost of rearing balady chickens farmyard (Namatalla, 2006). Newcastle disease (ND) and Infectious bursal disease (IBD) viruses have been noted to aggravate the symptoms of coccidiosis (Graat et al., 1998). Stress inducing factors as post vaccination reactions and other stresses are known to alter the clinical manifestation and severity of coccidiosis (Perry et al., 2000). As coccidiosis is an important parasitic disease of chickens, it alter both hematology and immune responses following Newcastle disease (ND) and Infectious bursal disease (IBD) vaccination in broilers (Akhtar et al., 2014). In Egypt, numerous research papers were carried on 
coccidiosis of commercial white broilers, but few of them carried on Egyptian balady breed chicken flocks (Abu Elezz, 1994).

Although coccidiosis has been the subject of a lot of research over the last decades, a number of very significant questions remain unanswered. As poultry production is subject to continuous changes, also the problems related to coccidiosis change over the years. Therefore, our work conducted to these problems of coccidiosis, both incidence and severity under the stresses followed the application of routine viral vaccinations.

\section{MATERIAL AND METHODS}

\subsection{Chickens and Experimental design}

Eight hundred, 1- day old balady chicks were divided into 8 equal groups as following: G1, G2, G3 and G4 were not infected artificially, while G5, G6, G7 and G8 were infected by a mixed field Eimeria oocysts. G1, G2, G5 and G6 were vaccinated by routine viral vaccines, while the other groups were' not vaccinated. G1, G3, G5 and G7 were fed on balanced anticoccidial containing ration, while the remaining groups were fed on balanced anticoccidial free ration.

\subsection{Ration}

The ration was provided ad-libitum from 1 day till the end of experimental work (32 days) as following: Anti coccidialcontaining ration for feeding groups $(1,3,5$ and 7). Anti coccidial-free ration for feeding groups $(2,4,6$ and 8$)$.

\subsection{Viral vaccines}

Nobilis IB 120, was used against Infectious Bronchitis. Hitchener B1 strain and LaSota strain against Newcastle disease were used. Gumboro 228E (Intervet International) used against Infectious Bursal disease.Chicks were vaccinated as in table (1).

\subsection{Mixed field sporulated oocysts culture (Davis, 1973)}

Oocysts were recovered from samples within $24 \mathrm{hrs}$. of their collection from farms, cleaned by salt flotation, washed, resuspeded in $2.5 \%$ potassium dichromate slution, sporulated, preserved at $4^{\circ} \mathrm{C}$ till used for the artifically infection of groups (G5, G6, G7 and G8) at 9 days old, at a dose of 150 sporulated oocysts for each chick given orally.

\subsection{Sample collection (Kumar et al., 2014)}

Freshly deposited 5-10 grams fecal samples were collected from each chick group following a ' $\mathrm{W}$ ' pathway. The collected samples were refrigerated and preserved in cold icebox and stored at $4^{\circ \mathrm{C}}$ until transportation for further processing.

\subsection{Laboratory parasitological examination}

\subsubsection{Direct microscopic examination (Urquhart, 1996).}

\subsubsection{Concentration floatation technique (Soulsby 1982)}

This method is based on the principle that the lighter parasitic oocysts float onto the surface of a saturated solution and the floating oocysts can be easily skimmed out of the surface film as the higher the S.G of the solution, the more the eggs of various types will float (Molan et al., 2009).

\subsubsection{Counting of oocyst of Eimeria species} (Fleck and Moody, 1988)

Stool egg counting technique, fill a graduated tube at the 14 level with $0.1 \%$ sodium hydroxide, add feces until level rise to $15 \mathrm{ml}$ and mix well. Take off $0.15 \mathrm{ml}$ from the suspension and transfer it to a slide, put a cover and count the oocysts. The numbers of oocysts per gram feces were calculated by multiplying the number of oocysts by 100. The low infection was $<200$ oocyst/ gm, medium infection was 200-500 oocysts/ gm and sever infection was $>500$ oocysts/gm. (Ahmed et al., 2013).

\subsubsection{Modified Wisconsin Sugar Flotation Method}

It is a modification of the stool dilution technique. Fill a $15 \mathrm{ml}$ test tube with $10 \mathrm{ml}$ of Sheather's solution and weight 1 gram of 
feces then place into a cup and pour the Sheather's solution into a cup and mix well, pour the fecal-sugar solution mixture through the strainer into the test tube, then centrifuge the tube for 2 to 4 minutes. Fill the tube to just over the top with Sheather's solution and place a cover slip onto the meniscus then let sit for about 5-10 minutes, and then remove the cover slip and place on a slide. Examine the entire cover slip and count the number of oocysts that you find. The oocysts are easier to see in Sheather's solution compared to salt solutions, provided that the light is properly adjusted (the condenser up and iris diaphragm closed enough to increase contrast); which makes them easier to notice against a white background (Dryden et al., 2005).

\subsubsection{Safranin-methylen blue staining technique}

Staining of Cryptosporidial oocytes were carried according to Baxby et al. (1984), where Cryptosporidium oocyst appeared orange against bluish background.

\section{RESULTS}

Results in table (2) revealed that (G1) vaccinated, non-infected and (G3) nonvaccinated, not infected, but the two groups were fed on anticoccidial containing ration, showed no infection with Eimeria or Cryptosporidium oocysts. While (G2) vaccinated, not infected and fed on anticoccidial free ration showed incidence of Eimeria (64\%) as 16 out of 25 examined samples were positive. The present study also revealed that (G4) which was not vaccinated not infected and fed on anticoccidial free ration showed incidence of Eimeria oocysts (60\%), and incidence of Cryptosporidium (40\%). From this results it was recorded that the total incidence rate of enteric protozoa among non-artificially infected groups was (41\%) of which $31 \%$ for Eimeria and 10\% for Cryptosporidium. Table (3) showed that both (G5) vaccinated, infected and treated, and (G6) vaccinated, infected but not treated, the increasing rate of oocysts count per gram of feces was fast and suddenly specially after each vaccinal application. While (G7) not vaccinated, infected and treated, and even (G8) not vaccinated, infected and not treated, the oocysts count per gram feces was increased gradually. G (6) vaccinated, infected and not treated, the oocysts count began $\left(0.25 \times 10^{3}\right)$, then $\left(3.5 \times 10^{3}\right),\left(20 \times 10^{3}\right)$ and $\left(35 \times 10^{3}\right)$ at days $14,19,26$ and 30 of age respectively. While (G8) not vaccinated, infected and even not treated, the oocysts count began $\left(0.3 \times 10^{3}\right)$, then $\left(1.8 \times 10^{3}\right)$, $\left(12.5 \times 10^{3}\right)$ and $\left(25 \times 10^{3}\right)$ at days $14,19,26$ and 30 of age respectively. G (7) non vaccinated, infected and treated was the best group, as the oocysts count began ( $\left.0.15 \times 10^{3}\right),\left(0.5 \times 10^{3}\right),\left(0.1 \times 10^{3}\right)$ and eventually $\left(0.25 \times 10^{3}\right)$ at $14,19,26$ and 30 days old respectively. However, G (5) the vaccinated, infected and treated was considered the ideal group, because it was protected against both viral and parasitic protozoal diseases at the same time.

\section{DISCUSSION}

The non-infected, non-vaccinated and treated chickens of group (G4), Cryptosporidium oocysts suspected by direct smear method and confirmed by Safranin-methylen blue staining technique in samples examined at days 10,11, 12 of age (figure $1 \& 2$ ). These results were agree with Huber et al. (2005) who mentioned that Cryptosporidium oocysts were examined by optical microscopy observation under $400 \times$ magnification based on the shape of oocysts. In the present work, out of 25 examined samples from chickens group (G4), 10 samples were positive for Cryptosporidium spp. oocysts, representing $(40 \%)$ as incidence rate. This results were agreed with Goodwin et al. (1996) who found that out of 56 broiler there are 23 $(41 \%)$ in U. S. A. had Cryptosporidium. On the other hand our 
Table (1): Vaccination program for groups (1, 2, 5, and 6)

\begin{tabular}{cccccc}
\hline Age/days. & $8^{\text {th }}$ day & $14^{\text {th }}$ day & $18^{\text {th }}$ day & $23^{\text {th }}$ day & $28^{\text {th }}$ day \\
\hline Vaccine & $\begin{array}{c}\text { Hitchener } \\
\text { B1+I.B }\end{array}$ & $\begin{array}{c}\text { I.B.D } \\
\text { (Gamboro) }\end{array}$ & $\begin{array}{c}\text { N.D } \\
\text { LaSota }\end{array}$ & $\begin{array}{c}\text { I.B.D } \\
\text { (Gamboro) }\end{array}$ & $\begin{array}{c}\text { N.D } \\
\text { LaSota }\end{array}$ \\
\hline
\end{tabular}

Table (2) incidence of enteric protozoa among non-infected groups.

\begin{tabular}{|c|c|c|c|c|c|c|c|c|}
\hline \multirow{2}{*}{ Group. } & \multicolumn{2}{|c|}{ Chick no. } & \multirow{2}{*}{$\begin{array}{l}\text { Eimeria } \\
+ \text { ve No. }\end{array}$} & \multirow{2}{*}{$\begin{array}{l}\% \text { in } \\
\text { Ex. }\end{array}$} & \multirow{2}{*}{$\begin{array}{c}\text { Cryp.+ve } \\
\text { no. }\end{array}$} & \multirow{2}{*}{$\begin{array}{l}\% \text { in } \\
\text { Ex. }\end{array}$} & \multirow{2}{*}{$\begin{array}{c}\text { Total } \\
\text { protozoa } \\
\text { +ve no. }\end{array}$} & \multirow{2}{*}{$\begin{array}{l}\% \text { in } \\
\text { Ex }\end{array}$} \\
\hline & Total. & Ex. & & & & & & \\
\hline G 1 & 100 & 25 & 0 & 0 & 0 & 0 & 0 & 0 \\
\hline G 2 & 100 & 25 & 16 & 64 & 0 & 0 & 16 & 64 \\
\hline G 3 & 100 & 25 & 0 & 0 & 0 & 0 & 0 & 0 \\
\hline G 4 & 100 & 25 & 15 & 60 & 10 & 40 & 25 & 100 \\
\hline \multicolumn{9}{|l|}{ Chicks } \\
\hline No. & 400 & 100 & 31 & 31 & 10 & 10 & 41 & 41 \\
\hline
\end{tabular}

Table (3) oocysts count $\times\left(10^{3}\right) /$ gm. feces of the infected groups.

\begin{tabular}{lcccc}
\hline Group & G 5 & G 6 & G7 & G 8 \\
\hline $8-13 \mathrm{~d}$ & $-\mathrm{ve}$ & $-\mathrm{ve}$ & $-\mathrm{ve}$ & $-\mathrm{ve}$ \\
$14^{*} \mathrm{~d}$ & 0.1 & 0.25 & 0.15 & 0.3 \\
$15 \mathrm{~d}$ & 0.2 & 0.5 & 0.2 & 0.5 \\
$16 \mathrm{~d}$ & 0.5 & 1 & 0.3 & 0.8 \\
$17 \mathrm{~d}$ & 1 & 1.6 & 0.4 & 1 \\
$18^{*} \mathrm{~d}$ & 0.7 & 1.65 & 0.45 & 1.5 \\
$19 \mathrm{~d}$ & 1.6 & 3.5 & 0.5 & 1.8 \\
$20 \mathrm{~d}$ & 1.8 & 5 & 0.35 & 2 \\
$21 \mathrm{~d}$ & 1.8 & 5 & 0.3 & 2.5 \\
$22 \mathrm{~d}$ & 1.6 & 6 & 0.25 & 3 \\
$23 * \mathrm{~d}$ & 1.57 & 6 & 0.2 & 5 \\
$24 \mathrm{~d}$ & 2 & 9 & 0.15 & 8 \\
$25 \mathrm{~d}$ & 3.5 & 14.5 & 0.1 & 10 \\
$26 \mathrm{~d}$ & 5 & 20 & 0.1 & 12.5 \\
$27 \mathrm{~d}$ & 4 & 21.3 & 0.15 & 15 \\
$28^{*} \mathrm{~d}$ & 3.5 & 21.3 & 0.2 & 17.5 \\
$29 \mathrm{~d}$ & 7.5 & 30 & 0.2 & 20 \\
$30 \mathrm{~d}$ & 8.5 & 35 & 0.25 & 25 \\
$31 \mathrm{~d}$ & 5 & 25 & 0.15 & 23 \\
\hline
\end{tabular}

9 day (day of infection) $-14^{*} \mathrm{~d}(\mathrm{IBDV})-18^{*} \mathrm{~d}\left(\right.$ LaSota), $23^{*} \mathrm{~d}(\mathrm{IBDV})-28^{*} \mathrm{~d}$ (LaSota). 

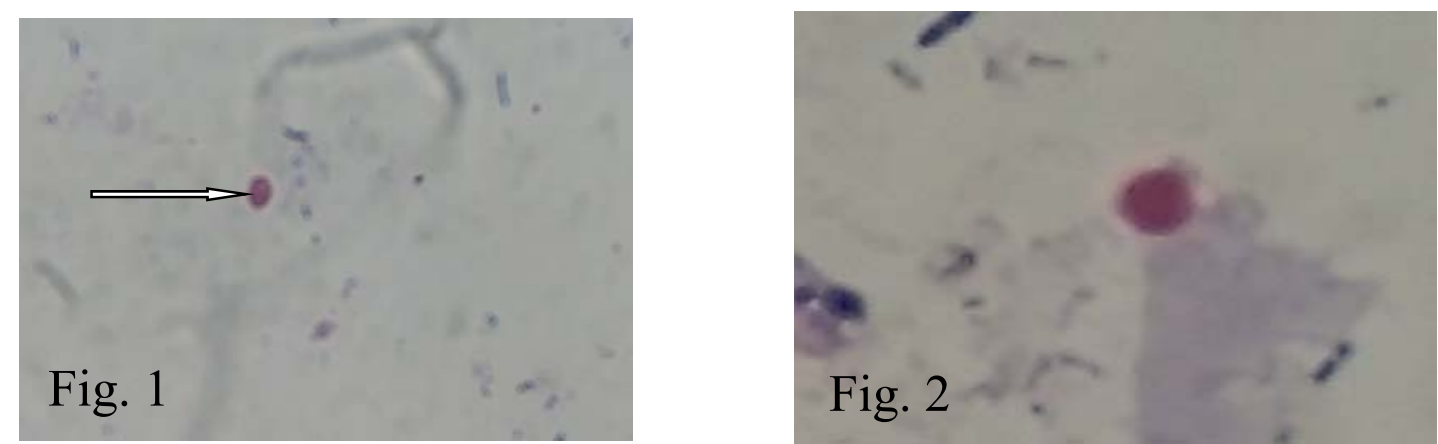

Figure (1), Figure (2): Safranin-methylen blue staining fecal smears from G4 at days 10, 11, 12 of age showed Cryptosporidium oocysts.

results disagreed with Soltane et al. (2007) who found that out of 200 broiler chickens (Gallus gallus) there were $9(4.5 \%)$ were infected by Cryptosporidium spp. in Tunisiea, this difference may be due to the number of examined samples which and environmental condition. The total incidence of Cryptosporidium was $10 \%$. Our results agreed with El-Gawady et al. (1998) and Ahmed (1992) who reported that the prevalence of cryptosporidiosis among broiler chickens at Port Said, Egypt was $10.38 \%$ and $9.05 \%$; respectively. While our results were disagreed with Rocha et al. (1996) who recognized Cryptosporidium spp. in $6(54.5 \%)$ out of 11 at 40 days old chicken and $2(18.18 \%)$ out of 11 at 47 days old chicken. This difference may be render to the age of examined chickens. The incidence rate of Eimeria was self-evident or logically $100 \%$ in the four infected groups (G5, G6, G7 and G8), as these groups were artificially infected at day 9 of age, and so all examined samples from these groups were positive for coccidian oocysts from the day 14 of age (5 days post infection) till the end of the experiment. But in the non-infected groups the incidence rate of Eimeria was equal to $31 \%$., because the public status of these chicks were good, so our results were consistent with Razmi and Kalederi (2000) who made a survey to detect the sub- clinical coccidiosis in broiler chicken in Iran and concluded that $38 \%$ had coccidiosis. These results also ran in parallel with Sood et al. (2009) who examined (117) fecal samples of poultry, and found (39) were positive for coccidial oocysts $(33.33 \%)$. While our results partially agreed with Kaingu et al. (2010) in Kenya, who recorded that 192 (27.04\%) out of 710 chickens (Gallas gallas) were infected with coccidial oocysts. However, these results were disagreed with Amer et. al. (2010) who recorded that the incidence of coccidiosis in native breeds was $90 \%$ in chickens in Egypt. This difference was due to the timing of infection, as in our experiment the infection of chickens with the disease occurred late, after the day 26 of chicken's age. Regarding the incidence rate of enteric protozoa, there were 41 out of 100 examined samples, had enteric protozoan among chickens groups, of which $31 \%$ incidence of coccidiosis and $10 \%$ incidence of cryptosporidiosis. This results were in parallel with El-Shall (2010) who mentioned that among varies parasitic infections; Eimeria was the major constraint for modern poultry production.

\section{CONCLUSION}

It is better to protect the Egyptian balady chickens against coccidia early, and at the time of its exposing to stress induced by viral vaccines applications, by previous treatment with effective drugs, and take all possible steps and managerial skills to prevent the infection of chicken with parasitic diseases, particular coccidiosis. The severity of coccidiosis and serious consequences, as low productivity, high mortalities and sever economic losses. Specially the balady breeds which grow more slowly and need 17 weeks to reach 
slaughter, and therefore could complete at most 3 cycles per year, which refers to the high cost of rearing balady chickens farmyard. We look forward to be able to eliminate and get rid of the parasitic diseases in the Egyptian farmyard chickens, to have high quality of meat and production our food, by our own hands to ease the economic burden on the Egyptian family.

\section{ACKNOWLEDGMENTS}

Special thanks for center of excellence in scientific research (CESR) faculty of veterinary Medicine, Benha University that found by management supporting excellence (MSE) and Benha University.

\section{REFERENCES}

Abu Elezz, N.T. 1994. Immunological studies on Eimeria species in fowls. Ph. D. Thesis, Fac. Vet. Med. Cairo Univ.

Ahmed, H.R. 1992. Some studies on Cryptosporidia"Coccidi "of chickens. M.V.Sc. Thesis, Fac. Vet. Med. Zagazig University.

Ahmed, N.E., El- Akabawy, L.M., El Madawy, R.S., Toulan, E. I. 2013. Studies on intestinal protozoa of poultry in Gharbia governorate. Benha Vet. Med. J., 25(2):78- 83.

Akhtar, M., Awais, M.M., Anwar, M.I., Syed, E.U., Nasir, A., Saleemi, M.K., Ashraf, K. 2014. The effect of infection with mixed Eimeria species on hematology and immune responses following Newcastle disease and Infectious bursal disease booster vaccination in broilers. Veterinary Quarterly Journal. The online platform for Taylor \& Francis Group content.

Amer, M. M., Awaad, M. H. H., ElKhateeb, R.M., Abu-Elezz, N. T, Abdelgayed, S.S., Ghetas, M.M., Kutkat, M.A. 2010. Isolation and Identification of Eimeria from Field
Coccidiosis in Chickens, J. Amer. Sci., 6(10):1107-1114.

Baxby, D., Dundell, N., Hart, C.A. 1984. The development and performance of a simple sensitive method for detection of Cryptosporidium oocysts in feces. J. Hyg. Camb., 92:317-323.

Blake, D.P., Tomley, F.M. 2014. Securing poultry production from the everpresent Eimeria challenge. Trends Parasitol., 30:12-19.

Chapman, H.D. 2014. Milestones in avian coccidiosis research: A review. Poult. Sci., 93: 501-511.

Davis, L.R. 1973. Techniques. In : D.M. Hammond and P.L. Long, (Eds.), The coccidia. University Park Press, pp. 411-458.

Dryden, M.W., Payne, P.A., Ridley, R., Smith, V. 2005. Comparison of Common fecal flotation techniques for the recovery of parasite eggs and oocysts. Vet. Ther., 6: 15-28.

El-Gawady, H.M., Elmeligy, A.A., Ghattas, M.W., Tadros, S.W. 1998. Studies on cryptosporidiosis of chicken at portsaid. Vet. Med. J. Giza, 46, (3): 293-302.

El-Shall, N.A. 2010. Studies on sensitivity of Eimeria isolates from chickens to some anticoccidial drugs, B.V.Sc. thesis, Fac. Vet. Med. dep. of poultry diseases Alexandria. University.

Fleck, S.L., Moody, A.H. 1988. Diagnostic technique in medical parasitology (1st. ed.), Baillere, Tindall, London.

Goodwin, M.A., Brown, J., Resurreccion, R.S., Smith, J.A. 1996. Respiratory coccidiosis (Cryptosporidium baileyi) among northern Georgia broilers in one company. Avian Dis. 40:572-575.

Graat, E.A., van der Kooij, E.; Frakena, K., Henken, A.M., Smeets, J.F., Hekeman, M.T. 1998. Quantifying risk factors in coccidiosis in broilers using on-farm data based on veterinary practice. Preventive Vet. Med., 33:297-308.

Huber, F., Bomfim, T.C., Gomes, R.S. 2005. Comparison between natural 
infection by Cryptosporidium spp., Giardia spp. in dogs in two living situations in the West Zone of the municipality of Rio de Janeiro. Veterinary Parasitology, 130:69-72.

Kaingu, F. B., Kibor, A. C., Shivairo, R., Kutima,H., Okeno,T.O., Waihenya, R., Kahi, A. K. 2010. Prevalence of gastro-intestinal helminthes and coccidia in indigenous chicken from different agroclimatic zones in Kenya. African Journal of Agricultural Research 5(6):458-462.

Kumar, S., Garg, R., Moftah, A., Clark, E.L., Macdonald, S.E., Chaudhry, A.S., Sparagano, O., Banerjee, P.S., Kundu, K., Tomley, F.M., Blake, D.P. 2014. An optimized protocol for molecular identification of Eimeria from chickens. Veterinary Parasitology 199(1-2):24-31.

Meeusen, Els. N. T., Walker, J., Peters, A., Pastoret, P. P., Jungersen, G. 2007. Current Status of Veterinary Vaccines. Clinical Microbiology Reviews, p. 499. American Society for Microbiology.

Molan, A., Liu, Z., De, S. 2009. Effect of pine bark (Pinus radiata) extracts on sporulation of coccidian oocysts. Folia Parasitol., 56:1-5.

Namatalla, A.A. 2006. Shortage in poultry supplies continues despite import legislation. Daily News Sept., 26.
Perry, P., Muruel, N., Yvore, P. 2000. Pathophysiology of coccidiosis. XXI World Poultry Conf. Montreal, Canada. Aug. 20-24, CDROM.

Razmi, R. Kalederi, G.A. 2000. Prevalence of sub clinical coccidiosis in broiler chickens in the municipality Khorasan. Iran. Preven. Vet. Med., 44 (3-4):247-253.

Rocha, R.J., Cordeiro, N.S., Madi, R.R., Franco, R.M. 1996. Detection of Cryptosporidium baileyi in cloacle and colonal smears from naturally infected fowls. Arquiro Brasleiro de medicina vetrinaria zzotecnia, 48(3):258-263.

Soltane, R., Guyotm, K., Dei-Cas, E., Ayadi, A. 2007. Prevalence of Cryptosporidium spp. (Eucoccidiorida: Cryptosporidiiae) in seven species of farm animals in Tunisia. Parasite, 14(4):335-338.

Sood, S., Yadav, A., Vohra, S., Katoch, R., Ahamad, D. B., Borkataki, S. 2009. Prevalence of coccidiosis in poultry birds in R. S. Pura region, Jammu. Veterinary Practitioner, 10:69-70.

Soulsby, E.J.L. 1982. Helminthes, Arthropods and Protozoa of Domesticated Animals. 6th Edn., Bailliere Tindall, London, pp. 56-58.

Urquhart, G.M. 1996. Veterinary Parasitology. 2nd Ed., ELBS, Longman House, Burnt Mill, Harlow, England. pp: 297-300. 